\title{
Do Females In Top Management Affect Firm Performance? Evidence From Pakistan
}

\author{
Muhammad Shaukat Malik \\ \& \\ Nida Zahoor
}

Al-Falah Institute of Banking and Finance

Bahauddin Zakariya University

\begin{abstract}
The purpose of this research is to examine the impact of females on top management on firm performance. For this purpose, proportion of the females on top management and firm performance are considered. Secondary data of KSE-100 index firms is used from the year 2010 to year 2014 for this research. STATA 13 is employed to analyze the data and formulate the results. Results revealed that the impact of females in top management on firm performance changes with the job they perform. There is significantly negative impact of female top managers on firm performance. Whereas, females on board does not have any significant impact on firm performance.
\end{abstract}

Keywords: Females in Top Management, Firm Performance, Gender Diversity.

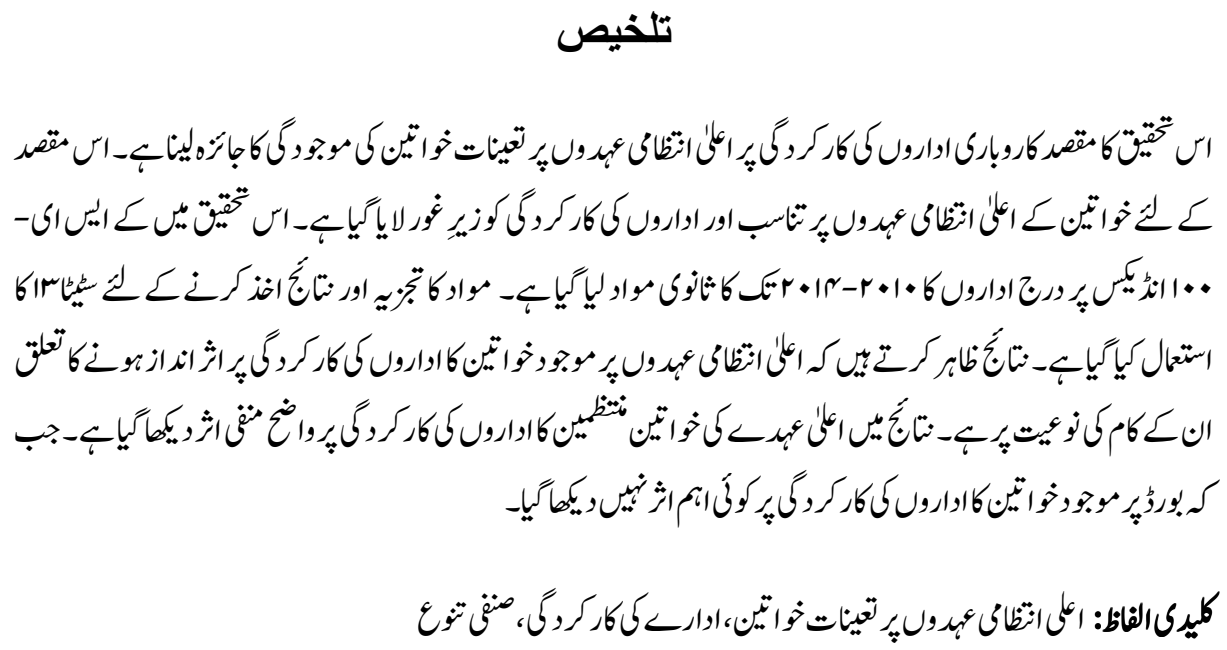

\section{Introduction}

Gender diversity has always been the topic of great interest all over the world. But females' representation in senior management and board of directors and its impact on firm performance is greatly emphasized from last decade (Yasser, 2012). Structure of board of directors, their qualification and their level in staff are the factors which have 
always been employed to increase the firm performance. Various combinations and constructs of these factors have been identified to increase firm performance. In recent studies gender is being considered as one of the aspect which can influence firm performance (Shafique, Idrees \& Yousuf, 2014).

Although Number of women working at middle level management is quite significant but it is quite low at top level (Oakley, 2000; Agars, 2004). This phenomenon is not only evident in developing countries but also in some developed countries. Recently in Grant Thornton International Business Report of 2013, it is reported that females constitute $35 \%$ of the global workforce and $24 \%$ of the global senior management. It was also reported that top five economies of the world have highest ratio of female CEOs.

Several questions had been raised to check whether there should be females on board or not and how they could benefit the firm. Results of previous studies encouraged researchers to conduct studies from different aspects in different scenarios in this regard. More researches are required to prove the importance of females in firms on top level. So the glass ceiling for women to work at top management could be removed and they can perform their role in increasing firm performance.

Very limited research has been conducted on this topic in Pakistan. Previous Pakistani studies revealed that proportion of females in top management is quite low (Mirza, Mahmood, Andleeb \& Ramzan, 2012; Shafique et al., 2014; Yasser, 2012). Women generally have been a neglected population segment in Pakistani firms specifically at top level. Irrespective of the high claims of gender equality from the government of Pakistan. Hence to increase the number of females in top management there is need to conduct more studies which can contribute towards creating parity. Because female's quota can only be increased when the impact and the reasons behind that impact of females in top management on firm performance will be analyzed. The purpose of this paper is same i.e. to examine the impact of females in top management on firm performance.

\section{Theoretical Framework and Literature Review}

Figure 1 represents the conceptual framework of this research. Evidence for all these presented variables and their relationship is rooted in the previous literature. Literature revelations are mixed; positive, negative and even no significant relation is found in the previous studies. These varying results are due to number of factors; including measures of firm performance, measure of female representation and sample. 


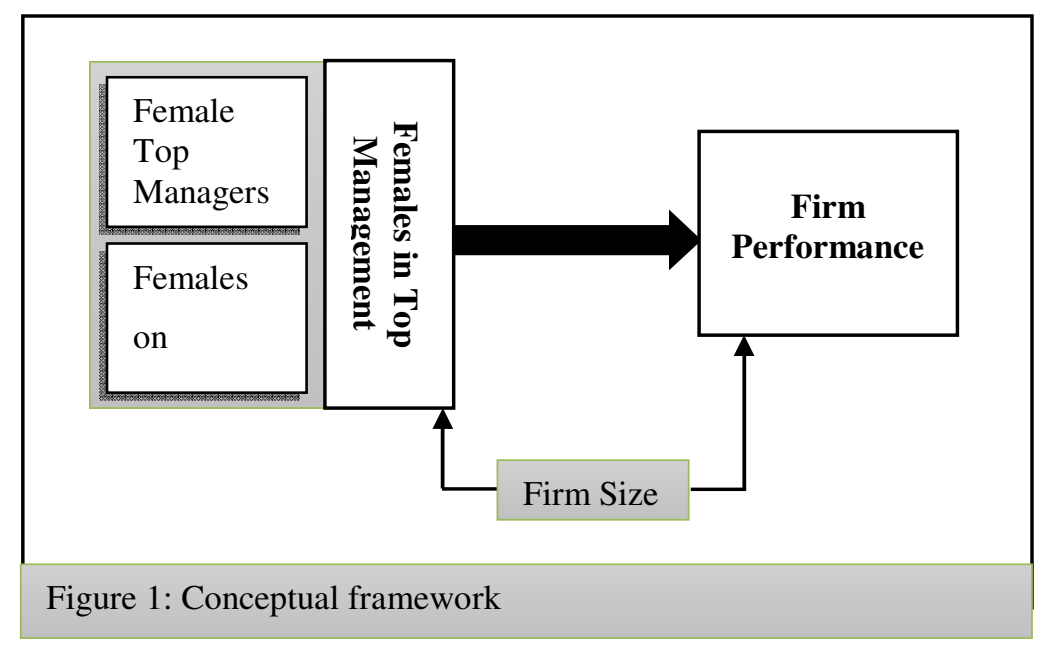

\section{Female Top Managers and Firm Performance}

Literature findings on the impact of female top managers on firm performance are mixed. Shrader, Blackburn \& Iles (1997) found that the firms with higher percentage of female managers also have higher firm performance in terms of ROS, ROA, ROI and ROE. Khan and Vieito (2013) also reported that firms with female CEOs have higher ROA as compared to the firms with male CEOs. Whereas gross profit ratio is also found to have positive and significant relation with the females in top management. But this positive impact is related to highly qualified female CEOs whereas less qualified CEOs does not influence firm performance (Smith, Smith, \& Verner, 2006). Izgi and Akkaş (2012) also found that female $\mathrm{CEO}$ can positively contribute in the firm profitability when measured by gross profit margin.

But females in top management can only increase firm performance when the firm's strategy is based on innovation. Innovation requires diversity and females can benefit innovative firms by their different management approach during managerial task performance (Dezsô \& Ross, 2012). But Kilduff, Anglemar and Mehra (2000) contradicts this view. They suggest that increase in diversity due to inclusion of female top managers could lead to decision making difficulty and hence can lower the firm performance. Many researchers reported negative correlation between female top managers and firm performance when measured by ROA (Shafique et al., 2014; Tobin's Q; Darmadi, 2010). Whereas Yasser (2012) revealed that there is no significant relationship between female top managers and firm performance. As most of the studies reported significant relationship between female top managers and firm performance, so it is hypothesized that:

H1: Higher proportion of female top managers have significant impact on firm performance. 


\section{Females on Board and Firm Performance}

The impact of females on firm performance changes with the role they perform in the firm (Petrova, Ghosh \& Xiao, 2013). Many studies which did not support any significant positive relation between female CEO and firm performance found the positive and significant relation between female board of directors and firm performance. Petrova, Ghosh and Xiao (2013) found the positive and significant impact of female board members on firm's profitability and Tobin's Q. Whereas Shafique, Idress and Yousaf (2014) found the positive and significant relation between ROA and female board members.

Carter, Simkins and Simpson (2003) conducted a research on fortune 100 firms. They found that Tobin's Q is positively related to the number of females present on board. Also the number of females increase as the firm size increases. Another research was conducted afterwards with a larger sample of fortune 500 firms. Results again showed positive and significant relationship between the two constructs (Carter, D'Souza, Simkins \& Simpson, 2007). Adams and Ferreira (2002) also found the same results with Tobin's Q. Apart from ROA and Tobin's Q; ROS (Liu, Wei, \& Xie, 2014) is also found to be positively affected by female board of directors.

But not all studies support the presence of females on board. Al-Shammari and Al-Saidi (2014) reported negative ROA and Tobin's Q in Kuwait. Whereas in Pakistan. ROE, ROE (Mirza et al., 2012) and economic value added are found to be negatively affected by females on board. There are many other researches which report that female on boards does not influence firm performance when measured by ROE(Bianco, Ciavarella, \& Signoretti, 2011; Tobin's Q; Bianco et al., 2011; Dang, Nguyen \& Vo, 2013; Rose, 2007) and ROA (Schwizer, Soana, \& Cucinelli, 2012). As the results are mixed and most of the studies revealed significant results, so it is hypothesized that:

H2: Higher proportion of females on board have significant impact on firm performance.

\section{Research Methodology}

\section{Sample and Data}

The purpose of this research is to analyze the impact of females in top management on firm performance in Pakistani firms with highest market capitalization. So, for this purpose the largest stock exchange of the Pakistan is selected. Sample is based on the KSE-100 index. KSE-100 index represents all the sectors of the KSE and includes the highest market capitalization firms which is $85 \%$ of all the market capitalization of the KSE (www.kse.com.pk). Sample comprised of the data over five years of the time period 
from 2010-2014. Sample was shortlisted due to unavailability of data. The final sample of 96 firms of KSE-100 index was selected which had complete data of all the required variables over the time period of 2010-2014.

Whole data is collected from the secondary sources. Data regarding females in top management is collected from the company' profile, company information about board of directors and management section of the annual reports of the respective firm. For the evaluation of firm performance, data is taken from the financial summaries and statements available in annual reports of the firm and the analysis reports of the respective firms issued by Karachi Stock Exchange.

\section{Variable Measurement}

\section{Females in Top Management}

Independent variable of this research is females in top management. It is measured on the basis of female top managers and females on board. These variables are adopted from the previous researches. For female top managers, proportion of female top managers is considered. During the data collection it was found that there is no female CEO in the Pakistani firms. Also there are very few firms which have female CFOs in their top management team. Females on board are calculated on the basis of proportion of females on board.

\section{Firm Performance}

Firm performance is the dependent variable of this study which measured by Tobin's Q.Tobin's Q has been utilized as an important tool for analyzing many corporate phenomenon previously (Chung \& Pruitt, 1994). It is the ratio of the market value of firm's assets to the replacement cost of firm assets (Tobin, 1969). It has been widely used in the studies of females in top management and firm performance by Adams and Ferreira (2002), Carter et al. (2003), Carter, D’Souza, Simkins\& Simpson (2007), Dezsö $\&$ Ross (2012) and Petrova et al. (2013). In previous researches different proxies for Tobin's Q has been utilized. For this research the Tobin's Q proxy is adopted from the studies of Adams \& Ferreira (2002) and Darmadi (2010).It is calculated as;

Whereas

$$
\text { Tobin's } Q=\frac{\text { Firm's market value }}{\text { Book value of assets }}
$$

Firm's market value $=$ Book value of assets - Book value of equity + Market value of equity 


\section{Firm Size}

Firm size is a control variable in this study. It is supported from the previous literature to control the relationship of females in top management and firm performance. Firm size is an important control for the firm performance and found to be positively influence the impact of females in top management on firm performance (Smith et al., 2006). Previously many researchers (Al-Shammari \& Al-Saidi, 2014; Dang et al., 2013) utilized firm size as a control to find the relationship between females in top management and board on firm performance. Firm size in this research is measured by total book value of the firm's assets.

\section{Data Analysis}

STATA 13 is utilized to for statistical testing. Descriptive statistics of the data reveals that there are 475 observations of the 96 companies in which every company's data is spread over 5 years (see Table 1). Values of Tobin's Qshows that in the data there are different companies in the sample including the companies which had been in loss and companies which showed tremendous performance. The minimum values of independent variables show that in data there are firms which have no female in their top management and maximum values shows that firms with $50 \%$ female top managers and $42 \%$ females on board. Values of firm size shows that firms in the sample have at least 0.37 million of assets whereas maximum asset value is 1867003 million.

Table: 1

\section{Descriptive Statistics}

\begin{tabular}{|l|l|l|l|l|l|}
\hline Variables & \multicolumn{1}{|c|}{ Obs. } & \multicolumn{1}{|c|}{ Mean } & \multicolumn{1}{c|}{ Std. Dev. } & \multicolumn{1}{c|}{ Min. } & \multicolumn{1}{c|}{ Max. } \\
\hline Companies & 475 & 48.43158 & 27.87807 & 1 & 96 \\
\hline Years & 475 & 3 & 1.415705 & 1 & 5 \\
\hline Tobin's q & 475 & 1.689242 & 2.988205 & -1.36 & 44.91 \\
\hline Female Top Managers & 475 & 0.0231579 & 0.1051948 & 0 & .5 \\
\hline Females on Board & 475 & 0.035801 & 0.0765699 & 0 & .4285714 \\
\hline Firm Size & 475 & 117041 & 248920.4 & .37 & 1867003 \\
\hline
\end{tabular}

Table 2 demonstrates the results of the correlation analysis of all the independent and control variables. As the issue of the multicollinearity only arises if correlation between variables is more than 0.8 (Cooper \& Schindler, 2007), so there is no problem of multicollinearity in the variables. 
Table: 2

Correlation Matrix

\begin{tabular}{|l|l|l|l|l|}
\hline & Tobin's Q & $\begin{array}{c}\text { Female Top } \\
\text { Managers }\end{array}$ & $\begin{array}{c}\text { Females on } \\
\text { Board }\end{array}$ & Firm Size \\
\hline Tobin's Q & 1.0000 & & & \\
\hline Female Top Managers & -0.0807 & 1.0000 & & \\
\hline Females on Board & 0.0809 & 0.1266 & 1.0000 & \\
\hline Firm Size & -0.0814 & -0.0249 & -0.1570 & 1.0000 \\
\hline
\end{tabular}

\section{Results and Discussion}

Pooled ordinary least square estimation is conducted to examine the relationship between variables. Results revealed that firm size controls the relationship between females in top management and firm performance. Considerable difference is found in the significance level of the relationship between females in top management and firm performance with the inclusion of "firm size" (see Table 3). So only the results with control variables are reported. As it is a panel data study so unobserved heterogeneity is also considered. For analyzing the impact of unobserved heterogeneity Breusch-Pagan LM and Hausman test are conducted. Both Breusch-Pagan LM and Hausman tests suggests that random effects model is more suitable for the data as compared to the pooled OLS model and fixed effects model respectively. This implies that the unobserved heterogeneity is not correlated to the observed variables and there are random effects of the omitted variables and individual characteristics of the female top managers and females on board. Results of all three models; pooled OLS, fixed effects and random effects are presented in the Table 3 .

Table: 3

Effect of females in top management on firm performance

\begin{tabular}{|l|l|l|l|}
\hline & $(1)$ & $(2)$ & $(3)$ \\
\hline Variables & OLS & Fixed Effects & Random Effects \\
\hline Female Top Managers & $-2.636^{* * *}$ & -0.140 & $-2.132^{* *}$ \\
\hline & $(0.685)$ & $(0.311)$ & $(1.074)$ \\
\hline Females on Board & 3.181 & 2.663 & 3.011 \\
\hline & $(3.306)$ & $(4.477)$ & $(4.582)$ \\
\hline Firm Size & $-8.52 \mathrm{e}-07^{* * * *}$ & $-2.15 \mathrm{e}-07$ & $-8.07 \mathrm{e}-07 * * *$ \\
\hline & $(2.51 \mathrm{e}-07)$ & $(4.19 \mathrm{e}-07)$ & $(3.11 \mathrm{e}-07)$ \\
\hline Constant & $1.736^{* * *}$ & $1.622^{* * *}$ & $1.725^{* * * *}$ \\
\hline & $(0.170)$ & $(0.163)$ & $(0.196)$ \\
\hline Observations & 475 & 475 & 475 \\
\hline R-squared & 0.020 & 0.001 & \\
\hline Number of id & & 95 & 95 \\
\hline
\end{tabular}

Robust standard errors in parentheses

$* * * \mathrm{p}<0.01, * * \mathrm{p}<0.05,{ }^{*} \mathrm{p}<0.1$ 
The results of OLS suggests that presence of female top managers have highly significant and negative impact on the performance of firm at $\mathrm{p}<0.01$. Results suggests that every $1 \%$ increase in the proportion of female top managers can reduce the firm performance by $26.36 \%$. Whereas, in case of random effects the significance level decreases from $p<0.01$ to $\mathrm{p}<0.05$. This suggests that if random effects of unobserved heterogeneity are considered then for every $5 \%$ increase in the proportion of female top managers the firm performance will decrease by $21.32 \%$. So, results suggests that higher the proportion of female top managers, lower will be the firm performance, with and without unobserved heterogeneity. As the results are significant so $\mathrm{H} 1$ is accepted. Results are consistent with the previous studies of Darmadi (2010), Izgi and Akkas (2012), Shafique et al. (2014), Smith, Smith and Verner $(2006,2008)$ and Yasser (2012).

Whereas in case of females on board no significant results are found for pooled OLS, fixed effects and random effects estimation. As all the results are insignificant so $\mathrm{H} 2$ is rejected. Previously Bianco, Ciavarella and Signoretti (2011), Dang et al. (2013), Rose (2007) and Schwizer, Soana and Cucinelli (2012) found the insignificant impact of the females on board on the firm performance. The reason behind insignificant effect of the females on board on firm performance could be the lower proportion of females on board in Pakistan. As the critical mass theory suggests that there is need of at least 3 females on board to eliminate the impact of gender in strategic decision making. Any proportion of females lower than that on boards of directors can be marginalized by the "group effect" in decision making (Kramer, Konrad, Erkut\& Hooper, 2006; Liu et al., 2014). Whereas, Del Prete and Stefani (2013) suggests that females are risk averters and hence they cannot play their role in risk related posts.

\section{Conclusions}

The purpose of this research was to examine the effect of females in top management on the firm performance. Results of this research revealed that higher proportion of female top managers have significantly negative impact on the firm performance. Whereas proportion of females on board does not have any significant impact on the firm performance. Results also suggests that there are random effects of the unobserved individual characteristics of females in top management. These unobserved characteristics could be; age, education and experience of the female top managers and females on board. So, it can be concluded that the effect of females in top management on firm performance is dependent on the role of females in top management. The relationship could vary from significant to insignificant as the status of the females in top management changes. 


\section{Limitations and Directions for Future Research}

There were some limitations of this research. First, few firms were dropped from the sample because of unavailability of data. Secondly, during data collection it was found that level of gender diversity is quite low at top level management in Pakistan. There are very few firms which have female top managers and none of them have female CEO. Also proportion of females on board is quite low. Most of the firms have only one female on their board. Apart from that, only one control variable and firm performance measure is employed in this research whereas there could be many other factors which can have stronger impact on the relationship of females in top management and firm performance. Individual effects should also be considered in the future researches as this research did not account them. Sector specific comparative analysis can be conducted, so it could be identified that which sector can benefit from the presence of females in top management.

\section{References}

Adams, R. B. \& Ferreira, D. (2002). Diversity and Incentives in Teams: Evidence from Corporate Boards. Working Paper, http://www.sbe.org.br/dated/ ebe24/052.pdf.

Agars, M. D. (2004). Reconsidering the Impact of Gender Stereotypes on the Advancement of Women in Organizations. Psychology of Women Quaterly, vol. 28, pp.103-111. http://doi.org/ 10.1111/j.1471-6402.2004.00127.x.

Al-Shammari, B. \& Al-Saidi, M. (2014). Kuwaiti Women and Firm Performance. International Journal of Business and Management, vol.9:8, pp.51-60. http://doi.org/10.5539/ijbm.v9n8p51.

Bianco, M., Ciavarella, A. \& Signoretti, R. (2011). Women on boards in Italy. Working Paper, retrieved from http://papers.ssrn.com/sol3/papers.cfm?abstract_id=1945855.

Carter, D. A., Simkins, B. J. \& Simpson, W. G. (2003). Corporate Governance, Board Diversity, and Firm Value. Financial Review, vol.38:1, pp.33-53.

Carter, D., D’Souza, F., Simkins, B. J. \& Simpson, W. G. (2007). The Diversity of Corporate Board Committees and Firm Financial Performance, http://papers.ssrn.com/sol3/papers.cfm?abstract_id=972763.

Chung, K. H. \& Pruitt, S. W. (1994). A Simple Approximation of Tobin's q. Financial Management, vol. 23, pp.70-74, http://ssrn.com/abstract=957032. 
Cooper, D. R. \& Schindler, P. S. (2007). Business Research Methods (10 ${ }^{\text {th }}$ ed.). New York: McGraw-Hill / Irwin.

Dang, R., Nguyen, D. K. \& Vo, L. C. (2013). Women on Corporate Boards and Firm Performance: A Comparative Study. Working Paper, http://events.emlyon.com/affi/papers/252.pdf.

Darmadi, S. (2010). Do Women in Top Management Affect Firm Performance? Evidence from Indonesia. Munich Personal RePEc Archive, (38743). http://mpra.ub.unimuenchen.de/38743/

Del Prete, S. \& Stefani, M. L. (2013). Women on Italian Bank Boards: Are They 'Gold Dust'? Bank of Italy Occasional Paper, (175). http://papers.ssrn.com/sol3/ papers.cfm?abstract_id=2297786

Dezsö, C. L. \& Ross, D. G. (2012). Does Female Representation in Top Management Improve Firm Performance? A Panel Data Investigation. Strategic Management Journal, vol.33:9, pp.1072-1089. http://doi.org/10.1002/smj.1955

Izgi, B. B. \& Akkaș, I. (2012). Do Women at the Top Make a Difference? Women in Management and Firm Performance in Turkey. European Journal of Economics, Finance and Administrative Sciences, vol. 53, pp.34-40.

Khan, W. A. \& Vieito, J. P. (2013). Ceo gender and firm performance. Journal of Economics and Business, vol.67, pp.55-66. http://doi.org/10.1016/j.jeconbus. 2013.01.003

Kilduff, M., Angelmar, R. \& Mehra, A. (2000). Top Management-Team Diversity and Firm Performance: Examining the Role of Cognitions. Organization Science, vol.11:1, pp.21-34. http://doi.org/10.1287/orsc.11.1.21.12569

Kramer, V. W., Konrad, A. M., Erkut, S. \& Hooper, M. J. (2006). Critical Mass on Corporate Boards: Why Three or More Women Enhance Governance. (Wellesley Centers for Women, Report No. WCW 11). Wellesley, MA: Wellesley Centers for Women.

Liu, Y., Wei, Z. \& Xie, F. (2014). Do Women Directors Improve Firm Performance in China? Journal of Corporate Finance, vol.28, pp.169-184. http://doi.org/10.1016/ j.jcorpfin.2013.11.016 
Mirza, H. H., Mahmood, S., Andleeb, S. \& Ramzan, F. (2012). Gender Diversity and Firm Performance: Pakistan. Journal of Social and Development Science, vol.3:5, pp.161-166.

Oakley, J. G. (2000). Gender-Based Barriers to Senior Management Positions: Understanding the Scarcity of Female CEOs. Journal of Business Ethics, vol.27:4, pp.321-334.

Petrova, M., Ghosh, C. \& Xiao, Y. (2013). Gender Diversity, Firm Performance and Corporate Decisions. Accademia Italiana di Economia Aziendale. http://www.aidea2013.it/docs/410_aidea2013_banking-and-finance.pdf

Rose, C. (2007). Does Female Board Representation Influence Firm Performance? The Danish Evidence. Corporate Governance: An International Review, vol.15:2, pp.404-413.

Schwizer, P., Soana, M. G. \& Cucinelli, D. (2012). The Relationship Between Board Diversity and Firm Performance: The Italian Evidence.Working Paper. Department of Banking and Insurance, Faculty of Economics, University of Parma, http://www.libertadigitale.it/adeimf/images/documenti/old/Convegni/Novara/Soana_ Schwizer_Cucinelli_Board_diversity.pdf.

Shafique, Y., Idress, S. \& Yousaf, H. (2014). Impact of Boards Gender Diversity on Firms Profitability: Evidence from Banking Sector of Pakistan. European Journal of Business and Management,vol.6:7, pp.296-307.

Shrader, C. B., Blackburn, V. B. \& Iles, P. (1997). Women in management and firm financial performance: An exploratory study. Journal of managerial issues, vol. 09, pp.355-372. http://www.jstor.org/stable/40604152.

Smith, N., Smith, V. \& Verner, M. (2006). Do women in Top Management Affect Firm Performance? A Panel Study of 2,500 Danish Firms. International Journal of Productivity and Performance Management,vol.55:7, pp.569-593. http://doi.org/ 10.1108/17410400610702160.

Smith, N., Smith, V. \& Verner, M. (2008). Women in top management and firm performance.Discussion paper no. 1708. Department of Economics. http://pure.au.dk/portal/files/32347041/dp1708.pdf 
Thornton, G. (2013). Women in Senior Management: Setting the Stage for Growth. Grant Thornton International Business Review, http://www.grantthornton.ae/ content/files/women-in-senior-management-ibr-2013.pdf

Tobin, J. (1969). A General Equilibrium Approach to monetary Theory. Journal of Money, Credit and Banking, vol.1:1, pp.15-29.

Yasser, Q. R. (2012). Affects of Female Directors on Firms Performance in Pakistan. Modern Economy, vol.03:07, pp.817-825.

Dr. Muhammad Shaukat Malik is Professor and Director in the Al-Falah Institute of Banking and Finance Bahauddin Zakariya University, Multan, Pakistan.

Nida Zahoor is Research Scholar in the Al-Falah Institute of Banking \& Finance, Bahauddin Zakariya University Multan. 